\title{
Napovedniki doživljanja medvrstniškega nasilja z vidika slovenskih is-letnikov: razlike po spolu med leti 2015 in 2018
}

\author{
Mojca Štraus, Ministrstvo za izobraževanje, znanost in šport \\ Klaudija Šterman Ivančič, Pedagoški inštitut
}

M edvrstniško nasilje v šolah je v Sloveniji pojav, o katerem se v zadnjih letih vedno več razpravlja tako $\mathrm{v}$ šolskem prostoru kot v širši strokovni javnosti. Razlog za to je dokaj pogosta prisotnost različnih oblik medvrstniškega nasilja v osnovnih in srednjih šolah, ki se, glede na rezultate študije HBSC (Jeriček Klanšček et al., 20I5 in 2019), z leti tudi povečuje. To predstavlja težavo, saj različne študije (npr. Gini in Pozzoli, 2009; Isaacs, Hodges in Salmivalli, 2008; Nabuzoka, Ronning in Handegard, 2009; Nishina in Juvonen, 2005; Rothon et al., 20II; Unnever, 2005) kažejo, da se doživljanje medvrstniškega nasilja, ne glede na vlogo posameznika $\mathrm{v}$ tovrstnih situacijah, pomembno povezuje $\mathrm{z}$ njegovo večjo odsotnostjo od pouka, zgodnjim opuščanjem šole, nižjimi učnimi dosežki, večjo pojavnostjo anksioznosti in depresije, nižjo samopodobo, večjo osamljenostjo, negativnimi spremembami v prehranjevalnih navadah in izgubi zanimanja za različne aktivnosti. Je torej pomemben dejavnik, ki učinkuje na posameznikov psihosocialni razvoj, šolsko in razredno klimo ter uspešnost mladostnika v šolskem in širšem socialnem kontekstu.

Namen tega prispevka je ugotoviti pogostost doživljanja medvrstniškega nasilja, kot so ga poročali učenci in učenke r. letnikov srednješolskih programov v okviru raziskave PISA 20ı8, primerjava omenjenih podatkov s tistimi, pridobljenimi v isti raziskavi leta 2015, ter ugotavljanje značilnih dejavnikov, ki pri učencih in učenkah zmanjšujejo verjetnost za izkušnje z različnimi oblikami medvrstniškega nasilja. Pri tem nas kot napovedniki posebej zanimajo pripadnost in občutek sprejetosti v šoli, čustvena opora staršev in bralni dosežek na preizkusu PISA, ki so se v že opravljeni 
nacionalni sekundarni analizi podatkov PISA 2015 (Šterman Ivančič, 2017) pokazali kot pomembni, preverimo pa jih lahko tudi s podatki raziskave PISA 20I8. V nadaljevanju najprej navajamo izsledke nacionalnih in mednarodnih študij s področja pogostosti različnih oblik medvrstniškega nasilja v slovenskih šolah. Temu sledi navedba izsledkov študij, ki so preučile povezanost medvrstniškega nasilja z občutkom pripadnosti in sprejetosti v šoli, bralnimi dosežki in čustveno oporo staršev. Ker je pričujoča študija do določene mere nadgradnja sekundarnih analiz, opravljenih na podlagi podatkov raziskave PISA 2015 (ibid.), v kateri so bile do določene mere že preverjene povezave med medvrstniškim nasiljem, učnimi dosežki, socialnimi dejavniki in nekaterimi dejavniki varnega in spodbudnega učnega okolja, v nadaljevanju navajamo tudi te izsledke. Poglavje zaključujemo z oblikovanjem raziskovalnih vprašanj.

Medvrstniško nasilje je v slovenskem šolskem prostoru relativno pogost pojav. Raziskovalci (Mugnaioni Lešnik et al., 2009) so na podlagi rezultatov nacionalnih analiz pogostosti različnih oblik medvrstniškega nasilja (fizično nasilje, psihološko nasilje, verbalno nasilje, ekonomsko nasilje, socialno izločanje in spolno nasilje) na slovenskih osnovnih šolah ugotavljali, da je fizično nasilje pogosto doživljalo 15 odstotkov učencev in učenk. Kot najpogostejše se je v povprečju pojavljalo besedno in psihološko nasilje, manj pa so učenci in učenke poročali o fizičnem in ekonomskem nasilju ter socialnem izločanju. Omenjene rezultate potrjujejo izsledki mednarodne raziskave HBSC ( $Z$ zdravjem povezana vedenja v šolskem obdobju) (Jeriček Klanšček et al., 2015), kjer so II-, I3-in I5-letniki poročali o tem, kako pogosto so v preteklih mesecih vsaj dvakrat sodelovali pri nasilju nad drugimi, kolikokrat so bili sami žrtev nasilja in kolikokrat so se v preteklih I2-ih mesecih pretepali. Rezultati so pokazali, da je leta 20149 odstotkov učencev in učenk v zadnjih nekaj mesecih vsaj dvakrat sodelovalo pri nasilju nad drugimi. ıo odstotkov se jih je v zadnjih nekaj mesecih pretepalo, 22 odstotkov učencev in učenk pa je poročalo, da so bili vsaj enkrat v preteklih parih mesecih žrtev nasilja. Podatki o trendih med leti 2002 in 2014 so v tej študiji nadalje pokazali, da se je sodelovanje učencev in učenk pri nasilju nad drugimi značilno povečalo ( 5 odstotkov v 2002 proti 9 odstotkov v 2014 ), in sicer predvsem pri II- in I3-letnikih (ibid.). Rezultati ponovne študije iz leta 2018 (Jeriček Klanšček et al., 2019) na področju trendov med leti 2002 in 2018 kažejo, da je odstotek II-, I3- in I5-letnikov, ki so sodelovali pri nasilju nad vrstniki, ostal približno enak (8\% mladostnikov iz vseh navedenih starostnih skupin je v zadnjih nekaj mesecih vsaj dvakrat sodelovalo pri nasilju nad vrstniki), delež tistih, ki so bili žrtve medvrstniškega nasilja vsaj enkrat v zadnjih nekaj 
mesecih, pa se je značilno zvišal predvsem pri I5-letnikih (2I \% v letu 2018 in $17 \%$ v letu 2014).

Tudi izsledki raziskave PISA, ki omogoča vpogled v zaznavanje prisotnosti različnih oblik medvrstniškega nasilja (fizično, verbalno in odnosno nasilje) pri I5-letnikih, iz leta 2015 (OECD, 2017a) za Slovenijo kažejo, da je 25 odstotkov učencev in učenk poročalo, da so nekajkrat v preteklem letu doživeli, da so se vrstniki norčevali iz njih. 20 odstotkov jih je poročalo, da so bili v zadnjem letu nekajkrat namerno izločeni iz dogajanja, približno desetina jih je poročala, da so jim v zadnjem letu nekajkrat grozili. Nekaj več kot petina jih je poročala, da so bili v zadnjem letu večkrat žrtev ekonomskega in fizičnega nasilja. Po poročanju učencev in učenk je bilo v največji meri prisotno odnosno nasilje v obliki obrekovanja oziroma širjenja grdih govoric, saj je kar 30 odstotkov učenk in 20 odstotkov učencev poročalo, da so to doživeli nekajkrat v preteklem letu. Verbalnemu in odnosnemu nasilju (norčevanje in širjenje grdih govoric) je sledilo namerno izločevanje iz skupnih aktivnosti, grožnje, ekonomsko nasilje (jemanje in uničevanje stvari) in fizično nasilje (udarjanje, porivanje). Podatki raziskave iz leta 2018 (OECD, 20I9) kažejo, da je v Sloveniji petina učencev in učenk (2 I odstotkov) poročala, da so najmanj nekajkrat mesečno žrtev različnih oblik medvrstniškega nasilja (v OECD 23 odstotkov), kar pomeni, da se je od leta 2015 delež učencev in učenk, ki so poročali, da so najmanj nekajkrat mesečno žrtev različnih oblik medvrstniškega nasilja, povečal za 4 odstotne točke.

Rezultati raziskave PISA (OECD, 20I7a) kažejo tudi, da prihaja v doživljanju različnih oblik medvrstniškega nasilja do značilnih razlik med spoloma. V letu 2015 rezultati kažejo, da so na povprečni ravni držav OECD fantje v povprečju poročali o pogostejšem medvrstniškem nasilju nad njimi kot dekleta, in sicer so se med fanti kot pogostejše pokazale vse oblike nasilja razen govoric, katerim so bolj izpostavljena dekleta. Izsledki podrobnejših nacionalnih sekundarnih analiz (Šterman Ivančič, 2017) teh podatkov, v katerih so bile preverjane razlike v doživljanju različnih oblik medvrstniškega nasilja po spolu znotraj posameznega srednješolskega izobraževalnega programa, so pokazali, da prihaja do teh razlik predvsem pri doživljanju ekonomskega in fizičnega nasilja ter pri širjenju grdih govoric, ostale oblike nasilja pa tako fantje kot dekleta doživljajo približno enako pogosto. Tako je približno ıo odstotkov fantov in 5 odstotkov deklet poročalo, da so jim v preteklem letu nekajkrat vzeli ali uničili stvari, 6 odstotkov deklet in kar 20 odstotkov fantov pa je poročalo, da so bili v zadnjem letu večkrat žrtev fizičnega nasilja (udarjanje, porivanje). Nasprotno so dekleta poročala o pogostejšem doživljanju t. i. odnosnega 
nasilja v smislu širjenja grdih govoric (30 odstotkov pri dekletih v primerjavi z 20 odstotki pri fantih).

Do razlik v doživljanju medvrstniškega nasilja pa prihaja tudi med učenci in učenkami z različnimi učnimi dosežki. Rezultati raziskave PISA 20I5 (OECD, 20I7a) kažejo, da na povprečni ravni držav OECD o doživljanju nasilja pogosteje poročajo učenci in učenke z nizkimi dosežki na preizkusu iz naravoslovne pismenosti PISA. Učenci šol, ki so v mednarodnem merilu beležile višjo prisotnost nasilja na šoli (kjer je več kot ıo odstotkov učencev in učenk poročalo, da so pogosto žrtve nasilja), so v povprečju dosegli 47 točk manj na preizkusu iz naravoslovne pismenosti kot učenci na šolah, kjer je o doživljanju nasilja poročalo manj kot 5 odstotkov učencev in učenk (ibid.). Omenjena razlika med šolami je ostajala tudi po upoštevanju razlik med šolami glede na socialno-ekonomsko ozadje njihovih učencev in učenk.

Tudi rezultati nacionalnih sekundarnih analiz podatkov raziskave PISA 2015 (Šterman Ivančič, 2017) so pokazali, da je pri pojasnjevanju pogostosti doživljanja medvrstniškega nasilja značilen napovednik dosežek na preizkusu PISA, in sicer predvsem dosežek na preizkusu iz bralne pismenosti.

$\mathrm{Z}$ namenom preprečevanja nasilnih dejanj $\mathrm{v}$ šolskem prostoru in učinkovitega spopadanja s posledicami medvrstniškega nasilja je pomembno, da skušamo pojasniti tiste dejavnike, ki se z nasiljem značilno povezujejo. Različni raziskovalci (npr. Astor in Meyer, 20or; Eliot et al., 2010; Gottfredson, 200I; Turner et al., 2002) ugotavljajo, da je pri preprečevanju pogostosti medvrstniškega nasilja ključno predvsem ustvarjanje varnega in spodbudnega učnega okolja, v smislu pozitivne šolske klime. Šolska klima se nanaša na šolska pravila, cilje, vrednote, odnose, način poučevanja, učenje, organizacijo in prakso pri vodenju šole. Pozitivna šolska klima pomeni, da se učenci počutijo varne, imajo izkušnjo pozitivnih odnosov z učitelji in ostalimi sošolci, občutek pripadnosti in povezanosti s šolo, občutek smiselnosti v sodelovanju pri odločitvah; pomeni tudi neodobravanje neprilagojenega vedenja med učenci, ozaveščenost glede nasilja tako med učitelji kot učenci in občutek učencev, da je sošolcem in ostalim na šoli mar zanje (Cohen in Geier, 20ıо; Osher et al., 20I2). Zgolj pravila, ki opredeljujejo nasilje in preprečevanje nasilja, ter vpetost teh $\mathrm{v}$ kurikulum ni dovolj, da se nasilje na šoli dejansko prepreči (npr. Katz, 1999; Noguera, 1995). Različne metaanalize (npr. Farrington in Ttofi, 2009; Merrel et al., 2008) kažejo tudi, da številni preventivni programi, ki so temeljili zgolj na omenjenem, niso pokazali oprijemljivih rezultatov. Šele ob spodbujanju pozitivne šolske klime je prišlo do zmanjšanja nasilja, bolj prosocialnega odzivanja na nasilno vedenje, večje zavzetosti 
za posredovanje pri tistih, ki nasilju prisostvujejo, in pogostejšega iskanja pomoči na šoli s strani tistih, ki so žrtev nasilja (Low in Van Ryzin, 20I4).

Rezultati raziskave PISA 2015 potrjujejo, da se doživljanje medvrstniškega nasilja značilno povezuje $\mathrm{z}$ občutkom pripadnosti in sprejetosti v šoli (OECD, 2017a). Na povprečni ravni držav OECD so rezultati raziskave pokazali, da je bilo med pogostimi žrtvami medvrstniškega nasilja 43 odstotkov takih učencev in učenk, ki so poročali, da se v šoli počutijo izločene. Med tistimi, ki niso poročali o doživljanju različnih oblik medvrstniškega nasilja, pa se jih je v šoli počutilo izločene 16 odstotkov učencev in učenk. Tudi izsledki nacionalnih sekundarnih analiz podatkov raziskave PISA 2015 (Šterman Ivančič, 2017) so potrdili, da učenci in učenke znotraj vseh izobraževalnih programov, ki poročajo o doživljanju nasilja, poročajo tudi o značilno nižjem občutku pripadnosti in sprejetosti v šoli kot tisti, ki ne poročajo o doživljanju medvrstniškega nasilja. Analiza razlik med spoloma znotraj izobraževalnih programov je nadalje pokazala, da ima večja pogostost doživljanja nasilja nekoliko bolj negativen učinek na občutek pripadnosti in sprejetosti v šoli pri dekletih kot pri fantih.

Zdrava čustvena navezanost mladostnika na starše, opora s strani le-teh, njihova razpoložljivost, razumevanje, pozitivna spodbuda, na drugi strani pa ustrezna mera avtoritete in zahtev so ključni pri razvoju mladostnikove pozitivne samopodobe, identitete, pozitivnega lastnega vrednotenja ter čustvene avtonomije (Rice, 200I; Marjanovič Umek in Zupančič, 2009), kar se odraža tudi v kakovosti odnosov mladostnika s pomembnimi osebami zunaj družine. Raziskave (npr. Booth-LaForce et al., 2006; Caples in Barrera, 2004; Laible, Carlo in Roesch, 2004, Miller, 1983; Rubin et al., 2004) namreč potrjujejo, da se večja čustvena opora staršev (pozitivna naravnanost staršev, njihova toplina in opora) značilno pozitivno povezuje z mladostnikovo ustrezno socialno-čustveno adaptacijo. Torej, mladostniki, ki poročajo o svojih starših kot o razumevajočih, spoštljivih, opornih in dojemljivih, v povprečju izražajo boljšo socialno kompetentnost, obenem pa poročajo o boljši kakovosti odnosov z vrstniki in so nasploh bolj zadovoljni sami s seboj. Nadalje so mladostniki, ki so v različnih raziskavah (npr. Field et al., 1995; Herman-Stahl in Peterson, 1996) svoj odnos s starši ocenili kot bolj oporen, v povprečju poročali o boljšem prilagajanju okolju izven družine in lažjem obvladovanju težjih situacij, pa naj bo to v šoli ali v vrstniških odnosih. Tudi pri zmanjševanju doživljanja medvrstniškega nasilja otrok se je čustvena opora staršev $\mathrm{v}$ smislu starševske prisotnosti, zavzetosti in topline $\mathrm{v}$ odnosu v različnih študijah (npr. Espelage, Bosworth in Simona, 2000; Olweus, 1993) pokazala kot pomemben napovednik. 
Podatki raziskave PISA 20Is kažejo, da so na povprečni ravni držav OECD o manj doživljanja medvrstniškega nasilja poročali učenci in učenke, ki so hkrati poročali tudi o večji opori s strani staršev v primeru težav v šoli. Ob tem je zanimivo tudi, da se je v is državah OECD, ki so $\mathrm{v}$ raziskavo vključile vprašalnik za starše, $\mathrm{v}$ povprečju za manj kot polovico (44 odstotkov) is-letnikov, ki so poročali o pogostem doživljanju medvrstniškega nasilja, pokazalo, da so njihovi starši v preteklem šolskem letu o težavah njihovega mladostnika z doživljanjem nasilja tudi spregovorili z učiteljem ali drugimi straši. Ena od možnih razlag za omenjene rezultate je lahko ta, da žrtve o doživljanju medvrstniškega nasilja vedno ne spregovorijo z drugimi (odraslimi) osebami, ali pa starši otrok o tem $s$ strani šole niso vedno seznanjeni (OECD, 2017a). Tudi rezultati sekundarnih analiz podatkov raziskave PISA 2015 (Šterman Ivančič, 2017) so potrdili, da je manjša zaznava čustvene opore s strani staršev pomemben napovednik pogostejšega medvrstniškega nasilja.

Varno in spodbudno učno okolje $\mathrm{v}$ smislu občutka sprejetosti in pripadnosti šoli ter kakovostni odnosi mladostnika s starši so se $\mathrm{v}$ preteklih študijah torej pokazali kot značilen napovednik medvrstniškega nasilja. $Z$ vidika ugotavljanja stabilnosti omenjenih napovednikov je pomembno, da te povezave preverimo na podatkih raziskave PISA, zbranih v različnih letih. Pričujoča študija tako predstavlja nadgradnjo in dopolnitev že opravljenih sekundarnih analiz (Šterman Ivančič, 2017), pri čemer nas pri pojasnjevanju medvrstniškega nasilja posebej zanima vloga občutka sprejetosti in pripadnosti šoli, čustvena opora staršev in bralni dosežki na preizkusu PISA. Ker je iz predhodnih rezultatov analiz (ibid.) že znano, da se doživljanje medvrstniškega nasilja med spoloma precej razlikuje, tako po vsebini, kot po pogostosti, smo raziskovalni vprašanji zasnovali ločeno glede na leto zbiranja podatkov in glede na spol. $S$ tem lahko dobimo nadaljnji vpogled $\mathrm{v}$ razlike med spoloma in med leti 2015 in 2018.

Raziskovalni vprašanji, ki ju $\mathrm{v}$ prispevku naslavljava, sta tako naslednji:

I) Kolikšne so spremembe v pogostosti doživljanja medvrstniškega nasilja I5-letnih deklet in fantov v Sloveniji med letoma 20I5 in 2018?

2) Kako občutek pripadnosti in sprejetosti $\mathrm{v}$ šoli, občutek čustvene opore staršev ter bralna pismenosti učinkujejo na doživljanje medvrstniškega nasilja? Kakšne so primerjave teh učinkov med letoma 2015 in 2018 ter med spoloma?

Pri naslavljanju drugega raziskovalnega vprašanja bomo upoštevali tudi bralne dosežke učencev, ki so se v predhodnih analizah tudi pokazali 
kot pomemben napovednik pogostosti doživljanja medvrstniškega nasilja (Šterman Ivančič, 2017).

\section{Metoda $^{\mathrm{I}}$}

$\mathrm{V}$ razdelku opisujeva posamezne mere in postopke, uporabljene $\mathrm{v}$ analizi raziskovalnih vprašanj. Uporabili bomo podatke iz raziskav PISA 2015 in PISA 2018. V raziskavi PISA I5-letni učenci in učenke po dveh urah reševanja preizkusa znanja iz bralne, matematične in naravoslovne pismenosti odgovarjajo še na vprašalnik o svojem ozadju, domačem okolju, zaznavanju šolskega okolja, odnosu do šolskega dela ipd. Raziskava se izvaja vsaka tri leta in Slovenija v njej sodeluje od leta 2006 . V letih 2015 in 2018 so vsi I5-letniki naloge reševali na računalnikih in prav tako so na računalnikih odgovarjali na vprašalnik.

\section{Vzorec}

Vzorec slovenskih I5-letnikov, ki so leta 2015 sodelovali v raziskavi PISA, je vključeval 6406 učencev, od tega 290 r deklet in 3505 fantov, ki skupaj reprezentativno predstavljajo 16.773 učencev ( 48 odstotkov deklet in 52 odstotkov fantov). Vzorec iz leta 2018 je vključeval 640 učenca, od tega 2993 deklet in 3408 fantov, ki skupaj reprezentativno predstavljajo 17.138 učencev (49 odstotkov deklet in $5 \mathrm{I}$ odstotkov fantov).

\section{Vključene spremenljivke}

Doživljanje medvrstniškega nasilja: Podatek je pridobljen iz odgovorov v vprašalniku za učence in učenke, in sicer na vprašanje »Kako pogosto si v zadnjih I2 mesecih na šoli doživel naslednje? (Nekatere izkušnje lahko doživiš na družbenih omrežjih.)《z naslednjimi postavkami: »Dijaki so me nalašč izločili iz dogajanja «, »Dijaki so se norčevali iz mene «, »Dijaki so mi grozili«, »Dijaki so mi vzeli ali uničili moje stvari «, »Dijaki so me udarili ali porinili« in $\gg$ Dijaki širijo grde govorice o meni « Za odgovor so učenci lahko izbirali med možnostmi: »Nikoli ali skoraj nikoli«, »Nekajkrat na leto «, »Nekajkrat na mesec $\ll$ in $\gg$ Enkrat na teden ali pogosteje $\ll .^{2}$

Doživljanje medvrstniškega nasilja skladno z ugotovitvami Sloberg in Olweus (2003) o primernih mejnih vrednostih določanja, da se nasilje

I V razdelku so navedene osnovne informacije o uporabljenih podatkih iz raziskave PISA. Podrobne informacije o zasnovi in izvedbi raziskave, na primer o vzorčenju, ter tehnični podatki o izpeljavi indeksov, kot na primer notranja skladnost uporabljenih lestvic, so na voljo v tehničnih poročilih obeh raziskav, OECD 2017b in OECD 2020.

2 V bazah PISA 2015 in PISA 2018 so spremenljivke poimenovane STo38Q03NA, STo38Q-

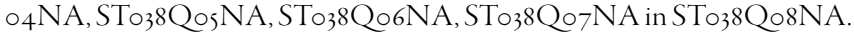


dogaja, opredeljujeva v primerih, ko so učenci vsaj pri eni postavki odgovorili, da se jim je to zgodilo nekajkrat na mesec ali pogosteje.

Občutek pripadnosti in sprejetosti $v$ šoli: Podatek je pridobljen iz odgovorov v vprašalniku za učence in učenke, in to na vprašanje $\gg$ Pomisli na svojo šolo: $\mathrm{v}$ kolikšni meri se strinjaš $\mathrm{z}$ naslednjimi izjavami? « $\mathrm{z}$ naslednjimi postavkami: »Počutim se izločenega (ali izobčenega) «, »V šoli z lahkoto sklepam prijateljstva $\ll, ~ \gg$ Čutim pripadnost do te šole $\ll, ~ \gg V$ svoji šoli se počutim čudno in odveč «, »Zdi se mi, da me imajo drugi dijaki radi« in »V šoli sem osamljen«. Pri vseh postavkah so učenci za izkaz svojega (ne)strinjanja lahko izbirali med odgovori $\gg$ Sploh se ne strinjam $\ll$, $\gg$ Ne strinjam se «, $\gg$ Strinjam se $\ll$ in $\gg$ Popolnoma se strinjam $\ll$. $^{3}$

$\mathrm{Na}$ podlagi odgovorov učencev so bili v bazah PISA 2015 in PISA 2018 na mednarodni ravni izpeljani indeksi na intervalnih lestvicah, za katere velja, da je povprečje OECD enako o in standardni odklon I, pri čemer je v standardizaciji vsem državam dodeljena enaka utež (OECD, 2019). Dodatno smo za lažjo interpretacijo rezultatov v tem članku vrednosti indeksa standardizirali na populacijo slovenskih I5-letnikov, ločeno za leti 2015 in 2018 . Negativna vrednost indeksa torej ne nakazuje neposredno negativnega odgovora na postavke, iz katerih je indeks izpeljan, ampak odgovore, ki so manj pozitivni (ali bolj negativni) od povprečnega odgovora v Sloveniji v letu 2015 oziroma v letu 20I8. Podobno pozitivna vrednost nakazuje bolj pozitivne (ali manj negativne) odgovore od povprečnega odgovora v Sloveniji.

Zaznavanje čustvene opore staršev: Podatek je pridobljen iz odgovorov v vprašalniku za učence in učenke, in sicer na vprašanje $\gg$ Pomisli na to šolsko leto: v kolikšni meri se strinjaš z naslednjimi trditvami? « po naslednjih postavkah: »Moji starši podpirajo moje izobraževalne napore in dosežke «, »Moji starši me podprejo, ko v šoli naletim na težave « in »Moji starši me spodbujajo k samozavesti«. Pri teh postavkah so učenci za izkaz svojega (ne)strinjanja lahko izbirali med odgovori »Sploh se ne strinjam $\ll, ~ \gg N e$ strinjam se «, »Strinjam se $\ll$ in $\gg$ Popolnoma se strinjam $\ll{ }^{4}$

Kot za občutek pripadnosti in sprejetosti v šoli je tudi za odgovore o zaznavanju čustvene opore staršev na mednarodni ravni izpeljan indeks, ki smo ga za analizo v članku standardizirali na populacijo slovenskih I5-letnikov ločeno za leti 2015 in 2018.

Bralni dosežek: Bralni dosežki v raziskavi PISA so mednarodno primerljive mere zmožnosti branja, ki so pripravljene na podlagi mednarodno usklajenih izhodišč in $\mathrm{z}$ mednarodno kontrolo ustreznosti prevajanja

3 Vbazah PISA je spremenljivka poimenovana BELONG.

$4 \quad$ V bazah PISA je spremenljivka poimenovana EMOSUPS. 
v jezike poučevanja is-letnikov (OECD, 2017b; OECD, 2020). Bralni dosežek slovenskih Is-letnikov je bil v letih 2015 in 2018 nad povprečjem OECD, in sicer 505 točk leta 2015 in 495 točk leta 2018 . Tudi bralne dosežke smo za analizo v tem članku standardizirali na populacijo slovenskih I5-letnikov ločeno za leti 2015 in 2018.

\section{Postopek obdelave podatkov}

$\mathrm{V}$ prvem koraku smo pripravili osnovne opisne analize pogostosti doživljanja medvrstniškega nasilja v letih 2015 in 2018 in ločeno po spolu. $\mathrm{V}$ ta namen smo izračunali odstotke odgovorov na posamezne postavke $\mathrm{v}$ vprašanju o doživljanju medvrstniškega nasilja in za tem odstotke tistih, ki so poročali o doživljanja medvrstniškega nasilja, glede na že omenjeno opredelitev. Ta analiza naslavlja prvo raziskovalno vprašanje. Za drugo raziskovalno vprašanje smo uporabili logistično regresijsko analizo, $s$ katero smo ugotavljali obete doživljanja medvrstniškega nasilja ob napovednikih občutka sprejetosti v šoli, zaznane čustvene opore staršev in bralnega dosežka. Tudi to analizo smo opravili ločeno za leti 2015 in 2018 in ločeno po spolu. Za vse vključene spremenljivke smo uporabili standardizirane vrednosti na populaciji slovenskih I5-letnikov, ločeno za leti 2015 in 2018.

Zaradi strukture dvostopenjskega vzorčenja v raziskavi PISA - posamezniki so vzorčeni znotraj predhodno vzorčenih šol - smo za izračune vzorčnih varianc in standardnih napak cenilk (ocenjenih vrednosti) uporabili ustrezne vzorčne uteži in vseh to ocen bralnega dosežka, ki so na voljo $v$ bazah PISA, ter metode bootstrap (OECD, $2017 \mathrm{~b}$; OECD, 2020). Za analize smo uporabili statistični paket SPSS 2 1.0 in za aplikacijo IDB Analyzer (IEA, brez datuma), ki omogoča tovrstne izračune. Pri stopnji tveganja 0,05 ugotavljamo statistično pomembnost vzorčnih razlik med primerjanimi količinami (npr. odstotki ali koeficienti v modelu) tako, da kot standardno napako razlike izračunamo koren vsote kvadratov standardnih napak obeh ocen količin. Ker se v predstavitvi rezultatov osredotočamo na posamezne primerjave, ne vključujemo večanja možnosti napake I. vrste, ki nastaja ob več hkratnih primerjavah (statistične pomembnosti razlik torej ugotavljamo brez popravka Bonferroni). V predstavitvi rezultatov navajamo le standardne napake ocen populacijskih parametrov, ostalih informacij o rezultatih preverjanja statistične značilnosti razlik pa zaradi ohranjanja berljivosti ne navajamo. Statistično pomembnost napovednikov $\mathrm{v}$ modelu logistične regresije ugotavljamo pri stopnji tveganja o,os s pomočjo testa Wald, ki ga omogoča aplikacija IDB Analyzer. $V$ predstavitvi rezultatov navajamo tudi vrednost $\mathrm{p}$.

Pri običajni linearni regresiji je za ugotavljanje pojasnjevalne moči modela $\mathrm{v}$ navadi ugotavljanje deleža $\mathrm{z}$ modelom pojasnjene variance $\mathrm{v}$ 
kriterijski spremenljivki. Pojasnjevalno moč napovednikov v logistični regresiji smo ugotavljali s formulo Nagelkerkejevega $\mathrm{R}^{2}$ (NKR), ki predstavlja pojasnjevalno moč v podobnem smislu.

Kompozitnih učinkov dejavnikov na ravni šol, kar bi zahtevalo hierarhične analize, nismo ugotavljali, ker raziskujemo povezanosti med napovedniki in doživljanjem medvrstniškega nasilja na ravni celotne populacije mladostnikov v Sloveniji. Preverili smo tudi, ali v modelu ni multikolinearnosti.5 Medsebojno povezanega delovanja napovednikov (interakcij) v model nismo vključili, saj so preliminarne analize pokazale, da bi jih bilo zelo malo statistično pomembnih z relativno majhnimi učinki. $\mathrm{Z}$ analizo smo tako ugotavljali le neto (suhi) linearni prispevek posameznega napovednika k obetom doživljanja medvrstniškega nasilja.

\section{Rezultati}

\section{Spremembe v pogostosti doživljanja medvrstniškega nasilja} med slovenskimi mladostniki med letoma 2015 in 2018

V Preglednici r so predstavljeni odstotki odgovorov učencev in učenk po posameznih postavkah vprašanja o pogostosti doživljanja določenih oblik medvrstniškega nasilja v šoli v zadnjih I2-ih mesecih iz raziskav PISA 2015 in PISA 2018.

Iz Preglednice $\mathrm{I}$ je razvidno, da v obeh letih precejšen delež učencev in učenk ne poroča o medvrstniškem nasilju; pri vseh postavkah so odstotki odgovorov, da se jim dogodki skoraj nikoli ne zgodijo, nad 60 odstotkov. Vendar pa precej fantov poroča, da vsaj nekajkrat na leto doživljajo norčevanje ( 32 oziroma 39 odstotkov) in širjenje grdih govoric (2I oziroma 32 odstotkov). Tudi za dekleta sta to obliki nasilja, o katerih doživljanju jih poroča veliko (o norčevanju je poročalo 2 I oziroma 26 odstotkov deklet in o širjenju grdih govoric 32 oziroma 29 odstotkov deklet). Is-letniki najmanj poročajo o doživljanju groženj, ki jih pogosteje doživljajo fantje (II oziroma 23 odstotkov) kot dekleta (s oziroma 9 odstotkov).

Deleži učencev in učenk, ki poročajo, da nasilje doživljajo najmanj tedensko, so sicer relativno majhni, vendar nezanemarljivi. Tako je na primer o najmanj tedenskem doživljanju širjenja grdih govoric o njih leta 2018 poročalo 4 odstotke fantov in 4 odstotke deklet.

Med spoloma so odgovori o pogostosti doživljanja nasilja pri večini postavk različni. Dekleta in fantje $\mathrm{v}$ obeh letih podobno odgovarjajo le o pogostosti doživljanja izločitve iz dogajanja, sicer pa večji delež fantov kot deklet poroča o doživljanju norčevanja, groženj, odvzemanju ali 
Preglednica ı: Odstotki odgovorov po posameznih postavkah medvrstniškega nasilja, ločeno po spolu za leti 2015 in 2018.

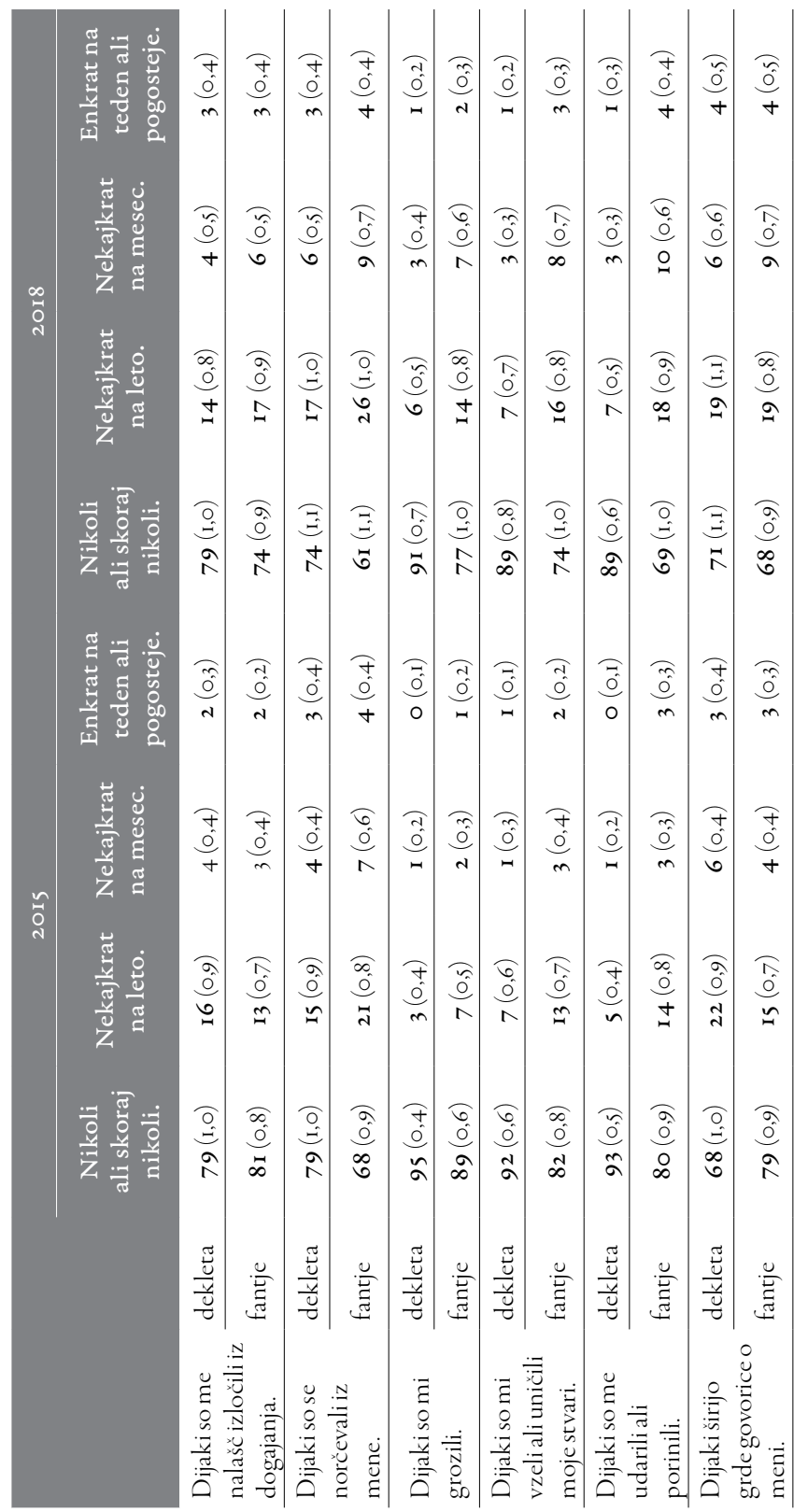

Opomba: Standardne napake so navedene v oklepajih. Vir: PISA 2015 in 2018 , lastni izračuni. 
uničevanju njihovih stvari, udarjanju in porivanju. Le malo večji delež deklet od fantov pa poroča o doživljanju širjenja grdih govoric o njih.

Odgovore učencev pri postavkah o doživljanju različnih oblik medvrstniškega nasilja smo združili v skupen kazalnik medvrstniškega nasilja glede to, ali doživljajo vsaj eno od oblik nasilja (podrobneje opisano v metodah). Učenci in učenke so bili na ta način razdeljeni na skupino tistih, ki v zadnjih I2-ih mesecih niso doživeli medvrstniškega nasilja, in skupino tistih, ki so medvrstniško nasilje doživeli. V Preglednici 2 predstavljava deleže učencev in učenk $\mathrm{v}$ teh dveh skupinah ločeno po letih in po spolu.

Preglednica 2: Deleži slovenskih is-letnikov, ki so v zadnjih I2-ih mesecih medvrstniško nasilje doživljali nekajkrat na mesec ali pogosteje, ločeno po letih in po spolu.

\begin{tabular}{lcc} 
dekleta & 2015 & 2018 \\
\hline fantje & $15(0,6)$ & $17(1,0)$ \\
\hline
\end{tabular}

Opomba: Standardne napake so navedene v oklepajih.

Vir: PISA 2015 in 2018 , lastni izračuni.

Preglednica 2 kaže, da je v letu 2015 o doživljanju medvrstniškega nasilja poročalo Is odstotkov deklet in I8 odstotkov fantov, v letu 2018 pa 17 odstotkov deklet in 25 odstotkov fantov. Deleži fantov, ki so poročali o doživljanju medvrstniškega nasilja, so bili leta 2018 višji kot $\mathrm{v}$ letu 2015, medtem ko je delež deklet ostal podoben. Podrobnejši pregled Preglednice 2 pokaže, da fantje v letu 2018 poročajo o več doživljanja medvrstniškega nasilja kot v letu 2015 na vseh postavkah, razlike pa so največje (za več od ıo odstotnih točk pri odgovoru »Nikoli ali skoraj nikoli«) pri postavkah, da so jim grozili, jih udarili ali porinili in da so o njih širili grde govorice. Za dekleta je največja razlika, 5 odstotnih točk, pri doživljanju norčevanja.

\section{Napovedniki doživljanja medvrstniškega nasilja}

Z drugim raziskovalnim vprašanjem smo ugotavljali učinek izbranih napovednikov na obete doživljanja medvrstniškega nasilja, ločeno po letih in po spolu. Rezultate analize predstavljava v Preglednici 3.

$\mathrm{Z}$ logistično regresijo smo ugotavljali obete doživljanja medvrstniškega nasilja, kar najlažje interpretiramo iz vrednosti koeficienta ExpB. Koeficient ExpB označuje izhodiščne obete pri povprečnih vrednostih napovednikov oziroma razmerje obetov doživljanja medvrstniškega nasilja učencev z za en standardni odklon večjo vrednostjo posameznega 
Preglednica 3: Rezultati logistične regresijske analize učinka napovednikov na doživljanje medvrstniškega nasilja, ločeno po letih in po spolu.

\begin{tabular}{|c|c|c|c|c|c|c|}
\hline \multicolumn{7}{|c|}{ DEKLETA } \\
\hline & & $\mathrm{b}$ & b.se & b.sig & ExpB & ExpB.se \\
\hline \multirow[t]{5}{*}{ PISA 2015} & izhodiščni obeti & $-I, 72$ & $(0,06)$ & 0,000 & $0, \mathrm{I} 8$ & $(0,0 \mathrm{I})$ \\
\hline & občutek sprejetosti v šoli & $-0,57$ & $(0,08)$ & 0,000 & 0,57 & $(0,05)$ \\
\hline & zaznana opora staršev & $-0,15$ & $(0,07)$ & 0,038 & 0,86 & $(0,06)$ \\
\hline & bralni dosežki & $-0,22$ & $(0,07)$ & 0,003 & $0,8 \circ$ & $(0,06)$ \\
\hline & NKR & 0,08 & $(0,02)$ & & & \\
\hline \multirow[t]{5}{*}{ PISA 2018} & izhodiščni obeti & $-1,72$ & $(0,08)$ & 0,000 & 0,18 & $(0,0 I)$ \\
\hline & občutek sprejetostiv šoli & $-0,85$ & $(0,10)$ & ০,০০০ & 0,43 & $(0,05)$ \\
\hline & zaznana opora staršev & $-0,15$ & $(0,08)$ & 0,053 & 0,86 & $(0,07)$ \\
\hline & bralni dosežki & $-0,22$ & $(0,08)$ & 0,005 & $0,8 \circ$ & $(0,06)$ \\
\hline & NKR & 0,05 & $(0,0 \mathrm{I})$ & & & \\
\hline \multicolumn{7}{|c|}{ FANTJE } \\
\hline & & $\mathrm{b}$ & b.se & b.sig & ExpB & ExpB.se \\
\hline \multirow[t]{5}{*}{ PISA 2015} & izhodiščni obeti & $-\mathrm{I}, 6 \mathrm{I}$ & $(0,06)$ & 0,000 & 0,20 & $(0,0 \mathrm{I})$ \\
\hline & občutek sprejetosti v šoli & $-0,30$ & $(0,05)$ & 0,000 & 0,74 & $(0,04)$ \\
\hline & zaznana opora staršev & $-0,24$ & $(0,06)$ & 0,000 & 0,79 & $(0,04)$ \\
\hline & bralni dosežki & $-0,14$ & $(0,07)$ & 0,042 & 0,87 & $(0,06)$ \\
\hline & NKR & 0,13 & $(0,02)$ & & & \\
\hline \multirow[t]{5}{*}{ PISA 2018} & izhodiščni obeti & $-\mathrm{I}, 22$ & $(0,06)$ & 0,000 & 0,29 & $(0,02)$ \\
\hline & občutek sprejetosti všoli & $-0,46$ & $(0,07)$ & 0,000 & 0,63 & $(0,05)$ \\
\hline & zaznana opora staršev & $-0,25$ & $(0,06)$ & 0,000 & 0,78 & $(0,04)$ \\
\hline & bralni dosežki & $-0,36$ & $(0,07)$ & ০,০০০ & 0,70 & $(0,05)$ \\
\hline & NKR & 0,13 & $(0,02)$ & & & \\
\hline
\end{tabular}

Opombe: b - koeficient, b.se - standardna napaka koeficienta b, b.sig - vrednost $\mathrm{p}$ za koeficient b po testu Wald $(\mathrm{df}=\mathrm{I})$, ExpB - razmerje obetov, ExpB.se - standardna napaka razmerja obetov.

Krepko so označena statistično značilna razmerja obetov ExpB.

Vir: PISA 2015 in 2018 , lastni izračuni.

napovednika glede na učence $\mathrm{z}$ manjšo vrednostjo napovednika. Naj najprej pojasniva, kako $\mathrm{v}$ članku razumeva obete. $\mathrm{V}$ prvem raziskovalnem vprašanju se je pokazalo, da je leta 2015 o doživljanju medvrstniškega nasilja poročalo is odstotkov deklet. Iz tega lahko razumemo, da je bila za dekleta v letu 2015 verjetnost doživljanja medvrstniškega nasilja o,ı 5 oziroma 
t. i. nedoživljanja medvrstniškega nasilja o,85 (I-0,I5). Obeti doživljanja medvrstniškega nasilja so razmerje med verjetnostjo doživljanja in nedoživljanja medvrstniškega nasilja, v našem primeru o,18 (0,15/(I-0,15)). Ti obeti kažejo, da so bile možnosti doživljanja medvrstniškega nasilja v populaciji slovenskih Is-letnih deklet v letu 2015 enake I8 odstotkov možnosti njihovega nedoživljanja. V enakem smislu navajava obete v nadaljnjem opisovanju rezultatov.

Rezultati v Preglednici 3 kažejo, kolikšen del variabilnosti v podatkih o doživljanju medvrstniškega nasilja lahko pojasnimo z izbranim modelom. V letu 2015 pojasnimo za dekleta 8 odstotkov in za fante 5 odstotkov, v letu 2018 pa tako za dekleta kot fante 13 odstotkov variabilnosti v teh podatkih. Rezultati torej kažejo, da so občutek sprejetosti v šoli, zaznava čustvene opore staršev in bralni dosežki v letu 2018 močnejši napovedniki (zmanjševanja) obetov doživljanja medvrstniškega nasilja kot v letu 2015.

Učinek posameznega napovednika na obete doživljanja medvrstniškega nasilja razberemo iz vrednosti koeficienta ExpB. Najprej, vrednost koeficienta ExpB za izhodiščne obete v modelu za dekleta v letu 2015 predstavlja obete doživljanja medvrstniškega nasilja deklet s povprečnimi vrednostmi napovednikov, torej s povprečnim občutkom sprejetosti v šoli, povprečno zaznavo čustvene opore staršev in povprečnimi bralnimi dosežki. Vrednost o, I8 nakazuje, da je verjetnost, da so ta dekleta doživljala medvrstniško nasilje, približno petina verjetnosti, da ga niso doživljala. Sama verjetnost doživljanja medvrstniškega nasilja teh deklet pa je is-odstotna $(0,18 /(\mathrm{I}+0,18))$.

Učinek posameznih napovednikov na obete doživljanja medvrstniškega pove, koliko so obeti doživljanja medvrstniškega nasilja večji ali manjši, ko dekleta s povprečnimi napovedniki primerjamo z dekleti, ki imajo izbrani napovednik od povprečja višji za en standardni odklon, po ostalih napovednikih pa sta si skupini deklet podobni. Napovednik z največjim učinkom je občutek sprejetosti v šoli. Vrednost koeficienta $0,57 \mathrm{za}$ ta napovednik predstavlja razmerje med obeti doživljanja medvrstniškega nasilja pri višjem občutku sprejetosti v primerjavi z obeti doživljanja medvrstniškega nasilja pri povprečnem občutku; obeti doživljanja medvrstniškega nasilja deklet $\mathrm{z}$ višjim občutkom sprejetosti so (le še) 57 odstotkov obetov za dekleta s povprečnim občutkom sprejetosti. Z drugimi besedami, ob ostalih napovednikih enakih se učinek boljšega občutka sprejetosti v šoli kaže v zmanjšanih obetih doživljanja medvrstniškega nasilja (zmanjšanje je za 43 odstotkov v primerjavi z obeti ob povprečnih napovednikih). Učinek čustvene opore staršev (ob ostalih dveh napovednikih enakih) se kaže v za I4 odstotkih zmanjšanih obetih doživljanja 
medvrstniškega nasilja, bralna pismenost pa v za 20 odstotkih zmanjšanih obetih doživljanja medvrstniškega nasilja deklet v letu 2015.

V letu 2018 so učinki izbranih napovednikov na zmanjševanje obetov doživljanja medvrstniškega nasilja deklet relativno podobni učinkom v letu 20I5. Najpomembnejši napovednik je ponovno občutek sprejetosti v šoli (zmanjšanje za 57 odstotkov), za njim višji bralni dosežki (zmanjšanje za 20 odstotkov), zaznava čustvene opore staršev pa se ni pokazala statistično pomembna (vendar vrednost p o,053 nakazuje, da je tudi ta napovednik smiselno upoštevati in da je, podobno kot v letu 2015, njegov učinek v zmanjšanju obetov za I 4 odstotkov).

Za fante v letu $2015 \mathrm{~s}$ povprečnim občutkom sprejetosti v šoli, povprečno zaznavo čustvene opore staršev in povprečnimi bralnimi dosežki so obeti doživljanja medvrstniškega nasilja o,20; verjetnost doživljanja medvrstniškega nasilja je torej petina verjetnosti nedoživljanja medvrstniškega nasilja (sama verjetnost doživljanja medvrstniškega nasilja pa je torej I7 odstotkov). Pri fantih vsi trije napovedniki zmanjšujejo obete doživljanja medvrstniškega nasilja, in sicer občutek sprejetosti v šoli za 26 odstotkov, zaznava čustvene opore staršev za 22 odstotkov in bralni dosežki za I3 odstotkov.

Za fante $\mathrm{v}$ letu $2018 \mathrm{~s}$ povprečnimi bralnimi dosežki in povprečnima občutkoma sprejetosti v šoli ter čustvene opore staršev so obeti doživljanja medvrstniškega nasilja višji od obetov za fante v letu 2015 z enako povprečnimi bralnimi dosežki in občutkom sprejetosti v šoli. Obeti doživljanja medvrstniškega nasilja za te fante so 0,29 , kar pomeni, da je verjetnost doživljanja medvrstniškega nasilja 29 odstotkov verjetnosti nedoživljanja medvrstniškega nasilja, in torej sama verjetnost doživljanja medvrstniškega nasilja enaka 22 odstotkov. Najbolj obete doživljanja medvrstniškega nasilja teh fantov zopet zmanjšuje občutek sprejetosti v šoli (za 37 odstotkov), za tem pa višji bralni dosežki (za 30 odstotkov) in nazadnje zaznana opora staršev (za 22 odstotkov).

\section{Razprava}

$S$ pričujočo raziskavo smo želeli ugotoviti pogostost doživljanja medvrstniškega nasilja z vidika Is-letnih učencev in učenk, ki praviloma obiskujejo prve letnike srednješolskih programov v Sloveniji. Pri tem smo izhajali iz podatkov raziskav PISA 20I5 in 20I8. Želeli smo ugotoviti tudi značilne dejavnike, ki pri učencih in učenkah zmanjšujejo verjetnost za izkušnje z različnimi oblikami medvrstniškega nasilja, kjer so nas posebej zanimali naslednji: pripadnost in občutek sprejetosti v šoli, čustvena opora staršev in bralni dosežek na preizkusu PISA. Pogostost doživljanja 
medvrstniškega nasilja in učinki omenjenih dejavnikov so nas zanimali ločeno po spolu in po letih 2015 in 2018.

Rezultati študije kažejo, da je prišlo med leti 2015 in 2018 do zvišanja deleža tistih učencev in učenk, ki so poročali o doživljanju medvrstniškega nasilja. Predvsem to velja za fante, delež deklet pa je ostal podoben. Rezultati za fante, nekoliko manj pa tudi za dekleta, se v letu 2018 razlikujejo tudi z vidika pojasnjevalne moči dejavnikov, ki zmanjšujejo obete doživljanja medvrstniškega nasilja: v letu 2018 je bila v primerjavi z letom 2015 pojasnjevalna moč modela, kamor so bili kot napovedniki doživljanja medvrstniškega nasilja vključeni občutek pripadnosti in sprejetosti v šoli, zaznana čustvena opora staršev in bralni dosežek, precej višja.

Izsledki pričujoče študije so skladni z rezultati različnih predhodnih študij (npr. Astor in Meyer, 200I; Eliot et al., 2010; Gottfredson, 200I; Turner et al., 2002), ki so obravnavale pomembnost pozitivne šolske klime (med drugim tudi pripadnost in občutek sprejetosti v šoli) za preprečevanje nasilja na šolah in iz katerih izhaja, da je ravno pozitivna šolska klima v smislu spodbudnega psihosocialno šolskega okolja mladostnika tisto, kar je v kontekstu zmanjševanja pogostosti medvrstniškega nasilja pomembno krepiti. Poleg tega so rezultati skladni s študijami (npr. Espelage, Bosworth in Simona, 2000; Olweus, 1993), ki so pri zmanjševanju pogostosti medvrstniškega nasilja kot pomemben dejavnik prepoznale oporni odnos s starši. Oporni odnosi in pozitivno vzdušje tako v šoli kot v družinskem okolju mladostnika se kažejo kot pomemben dejavnik pri preprečevanju doživljanja nasilja v šoli. Iz tega sledi, da bi v slovenskem šolskem prostoru veljalo uvajati preventivne programe za preprečevanje nasilja na šolah, ki poleg šole kot celote vključujejo tudi starše. Ob pregledu preventivnih programov s področja preprečevanja medvrstniškega nasilja na slovenskih osnovnih in srednjih šolah ugotavljamo, da teh v našem prostoru primanjkuje, se pa v zadnjem času vzpostavljajo preventivni programi (npr. NEON, 2020), ki skušajo v svoje aktivnosti poleg učencev in učiteljev vključevati tudi starše. Ta korak je nujen, saj različne pozitivne izkušnje s področja vpeljevanja preventivnih programov za preprečevanje nasilja v tujini (npr. Farrington in Ttofi, 2009; Merrell et al., 2008) kažejo, da je za dejansko preprečevanje medvrstniškega nasilja na šolah pomemben celostni pristop, ki poleg krepitve šolske klime in kulture, spodbujanja pozitivnih medosebnih odnosov na šoli, dviga zavesti o pomembnosti preprečevanja nasilja na ravni šole in vzpostavitve učinkovitega sistema obravnave nasilnih dogodkov, ko do njih pride, v prvi vrsti vključuje tudi starše. Ttofi in Farrington (20II) skozi metaanalizo 44 preventivnih programov za preprečevanje medvrstniškega nasilja, ki so zajemali različne deležnike učenčevega šolskega in domačega okolja, ugotavljata, da je večina 
programov v povprečju zmanjšala pogostost medvrstniškega nasilja na šolah za približno 20 do 23 odstotkov, nekateri tovrstni programi (npr. KiVa na Finskem in OBPP na Norveškem) pa celo za 40 do 50 odstotkov.

Rezultati pričujoče študije kažejo tudi na to, da obstajajo v slovenskem šolskem prostoru določene skupine učencev in učenk, ki poročajo o pogostejšem doživljanju medvrstniškega nasilja in katerim bi bilo treba $\mathrm{v}$ prihodnje posvetiti dodatno pozornost. To so predvsem fantje in učenci in učenke z nižjimi učnimi dosežki. Rezultati že omenjenih raziskav nakazujejo, da ima doživljanje medvrstniškega nasilja široke posledice na učenčevo počutje in uspešnost v šoli, najverjetneje pa se povezuje s specifičnimi psihosocialnimi dejavniki učnega okolja, vedenja in uspešnosti, ki bi jih veljalo dodatno raziskati. Temu pritrjuje tudi dejstvo, da smo z našim modelom relativno majhnega števila napovednikov doživljanja medvrstniškega nasilja uspeli pojasniti približno io \% variabilnosti v pogostosti doživljanja različnih oblik nasilja pri slovenskih I5-letnikih.

\section{Zaključek}

V kontekstu rezultatov pričujoče študije in širših raziskovalnih izsledkov zaključujemo, da sta pozitivna šolska klima v smislu spodbujanja pripadnosti in sprejetosti v šoli ter podporno domače okolje mladostnika pomembna pri zmanjševanju medvrstniškega nasilja. Ugotavljamo, da so pri tem uspešni predvsem celostni programi za preprečevanje različnih oblik nasilja na šoli. Gre za preventivne programe preprečevanja nasilja, ki pa v veliki meri temeljijo na sistemskem pristopu $\mathrm{k}$ preprečevanju nasilja, kar med drugim vključuje ozaveščanje o pomembnosti vloge vseh na šoli pri preprečevanju nasilja, vključevanju staršev in širše skupnosti ter vpeljavi jasnih pravil glede obravnave nasilnih dogodkov na šoli.

Avtorici kot izziv pedagoške prakse v slovenskem prostoru vidiva v oblikovanju celovitih programov za preprečevanje nasilja, ki bi zajemali naslednje: vodstvo šole (podpora aktivnostim proti nasilju, jasna stališča do nasilja, vzpostavitev jasnih postopkov obravnave nasilnih dogodkov, uvajanje preventivnih programov, sprotna evalvacija aktivnosti), strokovne delavce (podpora učiteljem, spodbujanje zavzetosti, usposabljanje učiteljev, organizacija aktivnosti, ki promovirajo varno in spodbudno šolsko okolje), učitelje (vzpostavitev spodbudne razredne klime, vključevanje učencev v proces odločanja, krepitev opornih odnosov z učenci), učence (vključenost pri vzpostavljanju spodbudne šolske klime, usposobljenost za proaktivno vedenje $\mathrm{v}$ situacijah nasilja, prevzemanje soodgovornosti, krepitev socialno-čustvenih kompetenc, medvrstniško mentorstvo), starše (sodelovanje v aktivnostih šole, komunikacija s šolo in učitelji pri obravnavi nasilnih dogodkov) in širše okolje (podpora pri uveljavljanju določenih 
zakonov in politike šole, pomoč pri pridobivanju potrebnih sredstev za izvedbo programov, podpora pri raziskovanju področja).

\section{Literatura}

Astor, R. A., in Meyer, H. A. (200I) The conceptualization of violence - prone school sub-contexts. Is the sum of the parts greater than the whole? Urban Education 36 (3), str. 374-399.

Booth-LaForce, C. L., Oh, W., Kim, A., Rubin, K. H., Rose-Krasnor, L., in Burgess, K. B. (2006) Attachment, self-worth, and peer-group functioning in middle childhood. Attachment and Human Development 8, str. $309-325$.

Caples, H. S., in Barrera, Jr., M. (2004) Conflict, support and coping ad mediators of the relation between degrading parenting and adolescent adjustment. Journal of Youth and Adolescence 35, str. 603-6r5.

Cohen, J., in Geier, V. K. (2010) School climate research summary (January 2010) New York: National School Climate Center.

Eliot, M., Cornell, D., Gregory, A., in Fan, X. (2010) Supportive school climate and student willingness to seek help for bullying and threats of violence. Journal of School Psychology 48, str. 533-553.

Espelage, D. L., Bosworth, K., in Simon, T. R. (2000) Examining the social context of bullying behaviors in early adolescence. Journal of Counseling and Development 78, str. 326-333.

Farrington, D. P., in Ttofi, M. M. (2009) Campbell systematic reviews: school-based programs to reduce bullying and victimization. Spletna stran: www.campbellcollaboration.org/lib/download/718/ (pridobljeno 20. 5 . 2020).

Field, T., Lan, G. C., Yando, R., in Bendell, D. (1995) Adolescent's intimacy with parents and friends. Adolescence 30, str. 133-I40.

Gini, G., in Pozzoli, T. (2009) Association between bullying and psychosomatic symptoms: A meta-analysis. Pediatrics I23, str. 1059-1065.

Gottfredson, D. (200r) Schools and Delinquency. Cambridge: Cambridge University Press.

Herman-Stahl, M., in Peterson, A. C. (1996) The protective role of coping and social resources for depressive symptoms among young adolescents. Journal of Youth and Adolescence 25, str. 733-753.

IEA (brez datuma) IDB Analyzer. Spletna stran: http://www.iea.nl/data. html (pridobljeno 20. I. 2020).

Isaacs, J., Hodges, E. V. E., in Salmivalli, C. (2008) Long-term consequences of victimization by peers: A follow-up from adolescence to young 
adulthood. International Journal of Developmental Science 2, str. $387-397$.

Jeriček Klanšček, H., Koprivnikar, H., Drev, A., Pucelj, V., Zupanič, T., in Britovšek, K. (2015) Z zdravjem povezana vedenja $v$ šolskem obdobju med mladostniki $v$ Sloveniji: Izsledki mednarodne raziskave HBSC 20I4. Ljubljana: Nacionalni inštitut za javno zdravje.

Jeriček Klanšček, H., Roškar, M., Drev, A., Pucelj, V., Koprivnikar, H., Zupanič, T., in Korošec, A. (2019) $Z$ zdravjem povezana vedenja v šolskem obdobju med mladostniki $v$ Sloveniji: Izsledki mednarodne raziskave HBSC 2oI8. Ljubljana: Nacionalni inštitut za javno zdravje.

Katz, S. R. (1999) Teaching in tensions: latino immigrant youth, their teachers, and the structures of schooling. Teachers College Record Ioo (I), str. $809-840$.

Laible, D. J., Carlo, G., in Roesch, S. C. (2004) Pathways to self-esteem in late adolescence: The roles of parent and peer attachment. empathy. and social behaviors. Journal of Adolescence 27, str. 703-716.

Low, S., in Van Ryzin, M. (2OI4) The moderating effects of school climate on bullying prevention efforts. School Psychology Quarterly 29, str. 306-319.

Marjanovič Umek, L., in Zupančič, M. (ur.) (2009) Razvojna psihologija. Ljubljana: Znanstvena založba Filozofske fakultete.

Merrell, K. W., Gueldner, B. A., Ross, S. W., in Isava, D. M. (2008) How effective are school bullying intervention programs? A meta-analysis of intervention research. School Psychology Quarterly 23, str. 26-42.

Miller, A. (1983) For your own good: Hidden cruelty in child-rearing and the roots of violence. New York: Free Press.

Mugnaioni Lešnik, D., Koren, A., Logaj, V., in Brejc, M. (2009) Nasiljev šolab: Opredelitev, prepoznavanje, preprečevanje in obvladovanje. Kranj: Šola za ravnatelje.

Nabuzoka, D., Ronning, J. A., in Handegard, B. H. (2009) Exposure to bullying, reactions and psychological adjustment of secondary school students. Educational Psychology 29, str. 849-866.

NEON. (2020) Program Neon: Varni brez nasilja. Spletna stran: http:// www.programneon.eu/o-projektu/ (pridobljeno II. 8. 2020).

Nishina, A., in Juvonen, J. (2005) Daily reports of witnessing and experiencing peer harassment in middle school. Child Development 76, str. $435-450$. 
Noguera, P. A. (1995) Preventing and producing violence: A critical analysis of responses to violence. Harvard Educational Review 65 (2), str. I89-2I2.

OECD. (2017a) PISA 2015 Results (Volume III): Students' well-being. Pariz, Francija: OECD Publishing.

OECD. (2017b) PISA 2015 technical report. Pariz, Francija: OECD Publishing.

OECD. (2019) PISA 20I8 Results (Volume III): What school life means for students' lives. Pariz, Francija: OECD Publishing.

OECD. (2020) PISA 2018 technical report. Pariz, Francija: OECD Publishing. https://www.oecd.org/pisa/data/pisazor8technicalreport/ (pridobljeno I 4. 8. 2020).

Olweus, D. (1993) Bullying at school: What we know and what we can do. Cambridge, MA: Blackwell.

Osher, D., Dwyer, K. P., Jimerson, S. R., in Brown, J. A. (2012) Developing safe, supportive and effective schools: facilitating student success to reduce school violence. V Jimerson, A. B., Nickerson, M. J., Mayer, M. J., in Furlong, J. (ur.). Handbook of school violence and school safety (2nd ed.). New York: Routledge.

Rice, F. P. (200I) Human development: a life span approach. Upper Saddle River (NJ): Prentice Hall.

Rothon, C., Head, J., Klineberg, E., in Stansfeld, S. (2011) Can social support protect bullied adolescents from adverse outcomes? A prospective study on the effects of bullying on academic achievement and mental health of adolescents at secondary schools in East London. Journal of Adolescence 34, str. 579-588.

Rubin, K. H., Dwyer, K., Booth-LaForce, C., Kim, A., Burgess, K., in RoseKrasnor, L. (2004) Attachment. friendship. and psychosocial functioning in early adolescence. Journal of Early Adolescence 24, str. 326-356.

Solberg, M. E., in Olweus, D. (2003) Prevalence estimation of school bullying with the Olweus bully/victim questionnaire. Aggressive Behavior 29, str. 239-268.

Šterman Ivančič, K. (2017) Sekundarna analiza podatkov raziskave PISA 2ors: Identifikacija napovednikov medvrstniškega nasilja iz podatkov raziskave PISA 2015 (interno neobjavljeno gradivo). Pedagoški inštitut: Ljubljana.

Ttofi, M. M., in Farrington, D. P. (20II) Effectiveness of school-based programs to reduce bullying: A systematic and meta-analytic review. Journal of Experimental Criminology 7, str. 27-56. 
M. ŠTRAUS, K. ŠTERMAN IVANČIČ • NAPOVEDNIKI DOŽIVLJANJA MEDVRSTNIŠKEGA NASILJA ...

Turner, J. C., Midgley, C., Meyer, D. K., Gheen, M., Anderman, E. M., in Kang, Y. (2002) The classroom environment and students' reports of avoidance strategies in mathematics: A multimethod study.Journal of Educational Psychology 94, str. 88-106.

Unnever, J. D. (2005) Bullies, aggressive victims, and victims: Are they distinct groups? Aggressive Behavior 3I, str. 153-I7I. 